\section{A NOTE ON \\ THE LOSS OF COMPLEMENTING POWER IN KEPT SERUM.}

By J. S. C. DOUGLas, D.M. Oxon., M.Sc. Birm.,

CAPTAIN, R.A.M.C. (T.F.); PROFESSOR OF PATHOLOGY IN THE UNIVERSITY OF SHEFTLELD : AND

J.W. BIGGER, M.B., B.CH. DUB.,

DEMFONSTRATOR IN PATHOLOGY IN THE UNIVERSITY OF SHEFFIELD. (From the Depantment of Pathology and Bacteriology in the University of sheffield.)

THE laws governing the disappearance of complement from sera are of the utmost importance in the elucidation of the problem of complement-fixation in the varions " lytic" and other phenomena. Owing to the difficulties in the determination of even the simplest instance of the loss of complementing power-i.e., in kept normal serum-the literature only contains vague and contradictory statements, such as:-

Complement "disappeared spontaneously if the serum was kept for a few days" (Emery 1); "Alexines ara of the most unstable nature" (Ehrlich and Morgenroth 2); "Rapidly, often within 24 hours, loses its atrength when kept at room temperature" (Muir and Ritehie 3 ); at ( 24 hours (Noguehi and Bronfenbrenner" ; Whilst Massol and Grysez, without indicating their methods of investigation, give some determinations showing that the complementing powers of sera decrease rapidly at the commencement, becoming inactive by about the sixteenth ary.

We have therefore endeavoured to determine the rate of loss of complementing puwer in kept normal serum in order to ascertain whether it is a regular phenomenon obeying definite physico-chemical laws. To this end we have elaborated a technique whereby the hamolytic complement content of a kept serum can be ascertained with some exactitude from day to day.

The chief difficulty in such an investigation is in the preparation of standard suspensions of red corpuscles, which can be kept for the purpose of the determinations. This we bave overcome by using sheep cells washed and stored in the manner described by Rous and Turner, ${ }^{6}$ since we find that the susceptibility of such cells to hæmolysin, although somewhat increased during the first 48 hours, subsequently appears to remain nearly constant for a greater length of time than that covered by our experiments. We therefore allowed at least 48 hours to elapse before using the cells, and in this way obtained a preparation suitable for the investigation. The preserved sheep cells were washed free of Rous and Turner's fluid with sterile normal saline and suspended in the latter in such strength that the hremoglobin liberated by distilled water and treated with $C O$ was exactly twice the strength of that in the standard tube of a Haldane-Gowers hæmoglobinometer. This method allows of accurate standardisation of the test corpuscular suspension day after day when made from the same batch of preserved blood, the suspension of red corpuscles of this particular density being termed the "standard corpuscular suspension."

Complement was obtained from guinea-pigs with aseptic precautions, The blood after collection was allowed to clot and the separated serum centrifuged to free it from corpuscles. This serum was stored at the desired temperature, the amount necessary for each determination being withdrawn with a sterile pipette and immediately titrated. Each of the sera $A, B$, and $C$ was obtained from a single healthy adult animal.

The immune body was a rabbit anti-sheep cell serum of high titre which was always used in the same dilution, so that three hæmolytic doses were present in each of the titration tubes.

\footnotetext{
Titration of Complement.
}

The complement-containing serum was so diluted as to cause standard hæemolysis in an amount between $1 \mathrm{c.cm}$. and $0.1 \mathrm{c.cm}$. of the dilution. Of this dilution $1.0,0.8,0.6,0.5$, $0.4,0.35,0.3,0.25,0.2,0.17,0.13,0.1 \mathrm{c.cm}$. were measured into small test-tubes of similar diameter which already contained sufficient saline to make the total volume in each tube $1 \mathrm{c.cm}$. As a control another tube containing $1 \mathrm{c.cm}$. of saline was prepared. To each was added $1.5 \mathrm{c.cm}$. of a mixture of two parts of standard corpuscular suspension and one part of diluted immune body. The tubes were shaken, placed in a water-bath at $37^{\circ} \mathrm{C}$. for two hours, then removed, shaken, and allowed to settle in the ice-chest till the following day, when the amount of serum required to produce standard hæmolysis was noted. Standara hæmolysis is equivalent to the hremolysis of 60 per cent. of the added corpuscles. It was determined by comparing the colour in a similar tabe containing $0.6 \mathrm{c.cm}$. of the standard corpuscular suspension hromolysed and made up to $2.5 \mathrm{ccm}$. with distilled water with the colours obtained in the titration tubes. It was thus found possible to make a very accurate estimation of the position of standard hæmolysis in the series by inspection. The strength of complement found in each specimen of serum is expressed in arbitrary units by multiplying the reciprocal figure of the actual amount of diluted serum giving standard hæmolysis by the number of times the serum was diluted.

The Fxperiments.

The experiments consisted in submitting complement as soon as it had been obtained free of cells (i.e., 21.5 hours after the collection of the guinea-pigs' blood) to temperatures of $9^{\circ} \mathrm{C}$. in the case of sera $A$ and $B$ and $20^{\circ} \mathrm{C}$. in the case of serum $C$, light being excluded. The temperatures were maintained as nearly constant as practicable until the removal of samples for titration had exbausted the specimens. The times at which the samples were taken and the number of units of complement found at the different intervals is recorded in the table for all three sera, whilst graphs of the results in the cases of sera $B$ and $C$ are also given. The duration of the experiments was, for $A, 211$ hours; for $B, 305.5$ hours ; and for $\mathrm{C}, 186$ hours.

\begin{tabular}{|c|c|c|c|c|c|c|}
\hline \multirow{2}{*}{$\begin{array}{l}\text { Time in } \\
\text { hours. }\end{array}$} & \multicolumn{2}{|c|}{$\begin{array}{l}\text { Exp. A. } \\
\text { Temp. }=9^{\circ} \mathrm{C}\end{array}$} & \multicolumn{2}{|c|}{$\begin{array}{c}\text { Hxp. B. } \\
\text { Temp. }=9^{\circ} \mathrm{C}\end{array}$} & \multicolumn{2}{|c|}{$\begin{array}{c}\text { Exp. C. } \\
\text { Temp. }=20^{\circ} \mathrm{C} .\end{array}$} \\
\hline & Obs. & $\begin{array}{c}\text { Calc. } \\
(\mathrm{n}=0 \cdot 3) .\end{array}$ & Obs. & $\begin{array}{c}\text { Calc. } \\
(n=0 \cdot 3) .\end{array}$ & Obs. & $\begin{array}{c}\text { Calc. } \\
(\mathrm{n}=0 \cdot 3)\end{array}$ \\
\hline $\begin{array}{c}0 \\
19 \\
44 \\
66 \\
90 \\
114 \cdot 5 \\
143 \\
162 \cdot 5 \\
186 \\
211 \\
234 \\
282 \cdot 5 \\
305 \cdot 5\end{array}$ & $\begin{array}{c}279 \\
228 \\
174 \\
140 \cdot 5 \\
113 \cdot 1 \\
75 \cdot 8 \\
72 \cdot 9 \\
62 \cdot 3 \\
53 \cdot 3 \\
45 \cdot 5 \\
- \\
-\end{array}$ & $\begin{array}{r}278.8 \\
225.5 \\
173.9 \\
140.5 \\
113.0 \\
91.7 \\
73.1 \\
63.1 \\
53.3 \\
44.9 \\
- \\
-\end{array}$ & $\begin{array}{l}258 \\
214 \\
171 \\
143 \\
115 \cdot 3 \\
95 \cdot 2 \\
76 \cdot 9 \\
62 \cdot 5 \\
57 \cdot 5 \\
52 \cdot 6 \\
42 \cdot 9 \\
33 \cdot 3 \\
28 \cdot 7\end{array}$ & $\begin{array}{c}258 \cdot 8 \\
214 \cdot 4 \\
170 \cdot 0 \\
140 \cdot 3 \\
115 \cdot 1 \\
95 \cdot 2 . \\
77 \cdot 3 \\
67.5 \\
57 \cdot 7 \\
49 \cdot 3 \\
42 \cdot 9 \\
32 \cdot 5 \\
28.7\end{array}$ & $\begin{array}{c}222 \\
161 \\
102 \\
65 \cdot 5 \\
52 \cdot 6 \\
31 \cdot 5 \\
28 \cdot 2 \\
24 \cdot 2 \\
15 \cdot 0 \\
- \\
= \\
-\end{array}$ & $\begin{array}{r}222 \cdot 3 \\
155 \cdot 1 \\
101 \cdot 8 \\
73 \cdot 1 \\
52 \cdot 7 \\
38 \cdot 9 \\
28 \cdot 2 \\
23 \cdot 0 \\
18 \cdot 3 \\
= \\
- \\
-\end{array}$ \\
\hline
\end{tabular}

Consideration of the Results.
An examination of the figures given in the table and of the curves shows that as time
progresses the complement decreases, but that 2004 it has not completely disappeared at the times when the sera were exhausted, the percentages of the original strengths remaining at the final estimations $150\left\{\begin{array}{l}\text { being } 16 \cdot 1 \text { (A), } 11 \cdot 2 \text { (B), and about } \\ 7(\mathrm{C}) \text {. This decrease is rapid at first }\end{array}\right.$ $150 \mid \begin{aligned} & \text { being } 16 \cdot 1 \text { (A), } 11 \cdot 2(\mathrm{~B}) \text {, and about } \\ & 7(\mathrm{C}) \text {. This decrease is rapid at first }\end{aligned}$

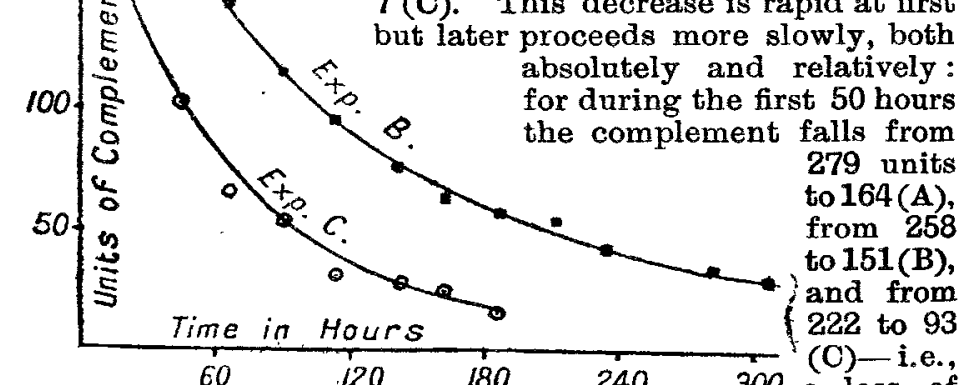

$120 \quad 180 \quad 240 \quad 300$ a loss of

41 per cent. (A), 41.5 per cent. (B), and 58 per cent. (O), whilst during the same length of time between the $136 \mathrm{th}$ and 186th hours the fall in complement is from 77 units to 53.3 (A), from 83 to $57.5(\mathrm{~B})$, and from 30 to $18(\mathrm{C})$, drops of 30.5 per cent. (A), 30.5 per cent. (B), and 40 per cent. (C).

These figures also prove that the loss is more rapid at the higher temperature, since Sera $A$ and $B$ were kept at $9 \circ \mathrm{C}$. and $\mathrm{C}$ at $20^{\circ} \mathrm{C}$., a point which is further emphasised by comparing the lengths of time required for a loss of 75 per cent. of the original strengths-i.e., 85 hours at $20^{\circ} \mathrm{O}$. (C), 150 hours (A), and 169 hours (B) at $90^{\circ} \mathrm{C}$, the loss at $20^{\circ} \mathrm{C}$. taking about half the time which is required to produce the same change at $9 \circ \mathrm{C}$.

The curves of loss of complementing power in the case of each serum are very regular throughout the ranges covered by the experiments (i.e., 1 to $1 / 6,1$ to $1 / 9$, and 1 to $1 / 12$ ), and the results are capable of being expressed by the formula $\frac{d x}{d t} \cdot \frac{1}{x^{n+1}}=K$, as can be seen in the table, where appear the figures calculated for each experiment from this formula after the graphic method given by Madsen. ${ }^{7}$ 
In this differential equation $x$ is the amount of complement remaining after the lapse of $t$ hours, $n$ and $K$ being constants.

Remarkable similarity is to be noticed between the results obtained experimentally and those calculated. In Experiment A, conducted at $9 \circ \mathrm{C}$, there is only one point of marked deviation-namely, that at 114.5 hours, which seems to be due to some accidental experimental error. In Experiment $B$, also at $9^{\circ} \mathrm{C}$., no error of such magnitude is present, the correspondence between observed and calculated results in both cases being highly satisfactory. Experiment O presents only moderate agreement between the calculated and the observed figures, but nevertheless is sufficient to indicate that the same formula may also hold good at $20^{\circ} \mathrm{C}$., as will readily be seen by inspection of the table and the curve, in which the observed points and the theoretical curve are shown.

Conclusions.

1. A satisfactory method of estimating decreases in the complementing powers of sera over considerable periods of time has been devised.

2. Whilst kept normal guinea-pig serum loses its complementing power more rapidly in the early stages than the later, and at $20^{\circ} \mathrm{C}$. than at $9^{\circ} \mathrm{C}$, , yet it retains its activity for a considerably longer time than has generally been conceded.

3. The loss of complementing power of such serum is perfectly regular and can be expressed by the formula$\frac{d x}{d t} \cdot \frac{1}{n+1}=K$, at $9{ }^{\circ} \mathrm{C}$, and apparently also at $20^{\circ} \mathrm{C}$.

References.-1. Hmery: Immunity and Specific Therapy, London, 1909. 2. Whrlich and Morgenroth: Ehrlich's Collected Studies, New York, 1906. 3. . Muir and Ritchie: Manual of Bacteriology, London, 1913. 4. Noguchí and Bronfenbrenner: J. Fxp. Med., xiii. 5. Massol
and Gryeez: Comptes Rendus Soc. Biol., Ixviii., 1910. 6. Rous and Turner:J. Exp. Med., xxiii., 1916. 7. Madsen : Festskrift ved Indvielse af Statens Seruminstitut, Copenhagen, 1902.

\section{KALA-AZAR IN MALTA: TWO CASES TREATED BY INTRAVENOUS INJEC- TION OF TARTAR EMETIC.}

BY H. 1. WINIFRED KERR, M.B., CH.B. Glasg., ATTAOHED R.A.M.C.

ALTHOUGH the occurrence of the infantile variety of kalaazar in Malta is well known to medical men practising in the island, it was believed until recently that the adult variety did not occur. Lately several cases have been described among military patients in which the disease developed in Malta. One such has been described by Lieutenants Brodie and Yorke, ${ }^{1}$ and Captain G. R. Ward has contributed to THE LANCET ${ }^{2}$ a short note on two cases in which the disease developed after the return of the patients to England.

In the present paper two further cases are recorded. One patient came direct from Fngland to Malta and had never been further East; the other patient had been invalided from Gallipoli with amcobic dysentery more than a year before he developed kala-azar, having been in "convalescent employ" in Malta. However, the cases acquire far greater interest and importance in that treatment by intravenous injection of tartar emetic, recently introduced by Sir Leonard Rogers, ${ }^{2}$ was conspicuously successful, recovery being to all appearance complete and permanent. In Case 1 diagnosis was reached at an early stage, and the response to treatment was much more rapid than in Case 2 , where patient was ill several months before treatment was initiated.

The recognition of kala-azar presents no special diffieulty when one is on the lookout for it. In the early stages the diagnosis rests upon general weakness and wasting, with raised temperature, sweating, conspicnous splenic enlargement, and pronounced leucopenia, this consisting of a marked relative diminution of polymorphonuclears and relative increase of mononuclear cells. The characteristic temperature chart, with its double daily rise, does not become conspicuous until rather later. For confirmation of the diagnosis splenic or hepatic puncture is necessary. Relying upon the signs mentioned above the diagnosis of yet a third case in one of the military hospitals was made within a few days of the patient first reporting sick.

1 R.A.M.C. Journal, January, 1917

2 ThE LaNCeT, 1916, ii., 16.
It is obvious that the treatment by tartar emetic should be resorted to in such cases as soon as the disease is recognised, for the cases here recorded tend to confirm its great value in a disease regarded hitherto as of specially evil prognosis.

CASR 1.-Sister B. Admitted Sick Sisters' Hospital Jan. 23rd, 1917. Age 29 vears. Service $17 / 12$ yexrs. Had nover been further east than Malta. Patient arrived on island in July, 1915; enjoyed good health till November. 1916, when she began to feel tired and more weary than usual. Slight eough in January, 1917; on Jan. 23 rd T. 100.8 $8^{\circ}$ F. She reported sick. Nothing abnormal detected in heart or lungs. Abdnmen moved freely; on left side was a mass, some doubt whether it was enlarged spieen or kidney. Urine acid ; sp. gr. 1008: trace of albumin a few granular and hyaline casts, no tuberele bacilli. She ran high .., which began to show indication of two rises in 24 hours from Feb. 12th; occasional rigor. Blood negative to Widal's reaction; no hæmoglobin fell from 52 to 30 per cent. no diarrbea.

On findings of blood picture, the leucopenia, marked anæmia, suggestive temperature, with mass in left side, now undoubtedly an enlarged spleen, splenic puncture was advised; Leishman-Donovan bodies recovered. In neither case could these parasites be recovered bodies recovered. In neither case could these parasite

On March lst intravenous injections of 2 per cent. solution of antiOn March lst intravenous injections of 2 per cent. Solution of antimony tartrate were commenced, and continued in increasing doses at four days intervals, beginning with $4 \mathrm{cccm}$. The Arst injection (2/3 gr.) was well borne; no marked reaction. By March 21st blood picture had
improved; T. only slightly raised ; patient had menstruated first time improved; T. only slightly raised; patient had menstruated first time
for three months. Spleen, which had been below umbilicus, had not for three months. Spleen, which had been below umbilicus, had not
altered mueh hitherto, but by March 24 th lower border was in inch above anterior iliac spine. About April T., which had been normai, ros to $100^{\circ}$; an injection given at once checked relapse. After first six injections intervals between had been gradually increased and had evidently become too long.

By May 31st spieen was only four fingers' breadth below costal margin; left kidney again palpable, low and enlar:ed. By June 5th spleen was not palpable and remained so without further treatment. hegaining weight; no rise of T. Patient was subsequently returned in a military hospital in England.

CASE 2.-Corporal C. Admitted Military Hospital, Imtarfa, Feb. 18th, 1917. Age 28. Service: 3 1/12 years. Foreign service: Egypt, September, 1914-August, 1915; Gallipoli, August, 1915-Oet. 28th, 1915; and in Gallipoli till invalided with amoebie dysentery in October, 1915 . and in Gallipoli till invalided with amoebic dysentery in October, 1915 . On recovery stool examined at Camp Hospital; found to be carrier of
E. histolytica. He was treated from May till July, 1916, Imtarfa E. histolytica. He was treated from May till July, 1916, at Imtarfa Hospital, being discharged back to Camp Hospital on July 9th, 1916. There he became a "convalescent employed" on orderly-room staff. There were plenty of fleas about, and a dog attached to the orderly.
room slept frequently on his bed and had special attention as it was then suffering from " distemper."

About end of 1916 patient began to feel very tired; was getting thinner. In January, although taking quinine, $10 \mathrm{gr}$. daily, T, rose. In beginning of February he was having 20 grains daily; $\dot{T}$. not controlled. Eventually he was sent into hospital again as case of P.U.O Nothing abnormal in heart or lungs. In abdomen tumour below left costal margin, about hand's breadth downward. It was not tender; apt to vary in position. Patient markedly emaciated; a curious in 24 hours, often as high as $104^{\circ}$ or $105^{\circ}$. No symptoms of dysentery; stool reports negative. Quinine given intramuscularly; no effect on $T$. Blood did not agglutinate dysenteries, typhoid, parat yphoid bacilli, nor Micrococcus melitensis. No malarial parasites found in films taken; marked leucopenia and anæmia. These, with spiking of temperature and enlarged spleen, led to suggestion of splenic puncture. On account of extreme debility hepatic puncture was resorted to and $L$. donovani recovered.

On March 7th treatment by tartar emetic in 2 per cent. solution (normal saline) was commeneed with $4 \mathrm{c.cm}$. intravenously, increased by 2 c.cm. and given every three days, till $10 \mathrm{c.cm}$. were reached. Marked general reaction each time. Reactions, with patient's debility and nervous condition, induced one to try $\frac{1}{4} \mathrm{gr}$. of morphine and $1 / 60 \mathrm{gr}$ of strychnine hypodermically, 20 minutes before injection. This had good effect, quieting general reaction of coughing, retching, and hysteria, and abolishing entirely rigor which used to come on abou two hours after injection. The $10 \mathrm{c.cm}$. dose had to be given within at least 60 to 90 seconds, or coughing and retching would begin, and became impossible to keep needle directly in vein. Tartar emetic causes an intense inflammation should any escape, followed by cold
abscess. Two of these occurred, but cleared up with treatment. There is less reaction when soiution is heated to blood heat.

is less reaction when soiution is heated to blood heat. By March 26th patient was being given $10 \mathrm{c.cm}$. doses of tartar
emetic, 2 per cent. solution ; condition critical. T. still rose to emetic, 2 per cent. solution ; condition critical. T. still rose to
$104^{\circ}$ twice daily; P. 120. Heart sounds fairly good; no dilatation or murmurs. His condition got steadily worse. He suffered greatly from night sweats. As condition was desperate, drug was pushed to its limit, and on March $31 \mathrm{st} 12 \mathrm{c.cm}$. of solution were given, followed by $10 \mathrm{c.cm}$. every other day until April 16th, when $\mathbf{T}$. rose once only to $101^{\circ}$. General condition much improved. T. did not rise again, and as his arms were very sore and suitable veins were not obtainable elsewhere
a week's respite was allowed, during which time $T$. did not rise. Veins a week's respite was allowed, during which time T. did not rise. Veins showed signs of inflammation and leakage at previous punctures where the solution had been given. $10 \mathrm{c.cm}$. and then $6 \mathrm{c.cm}$. were given at intervals of a week, but $T$. rose again with a smaller dose, with drowsiness and lack of appetite. On May $27 \mathrm{th}$ he was given $10 \mathrm{c.cm}$. and then $9 \mathrm{c.cm}$. of solution at interval of three days. This controlled
relapse and two more doses completed this treatment. The spleen by relapse and two more doses completed this treatment.
July 11th was only just palpable below costal margin.

During treatment patient suffered from no skin eruptions nor rashes, no gastric disturbances, no diarrhoea, and no ophthalmic symptoms. He was transferred to inngland as a "walking case," and writes that he has now taken up former occupation. Fxcept for the melancholy and depression, the antimony had no toxic effects, though given in such large and frequent doses; also no return of dysentery. Altogether
he had $424 \mathrm{cg}$. of tartar emetic : $246 \mathrm{cg}$. of tartar emetic being used in Case 1 . 